\title{
Peyer's Patch Lymphoid Follicle Epithelial Adherence of a Rabbit Enteropathogenic Escherichia coli (Strain RDEC-1)

\author{
Role of Plasmid-Mediated \\ Pili in Initial Adherence
}

\author{
Lindsey R. Inman and J. Robert Cantey \\ Veterans Administration Medical Center and Departments of \\ Pathology and Medicine, Medical University of South Carolina, \\ Charleston, South Carolina 29403
}

bstract. Escherichia coli (strain RDEC-1) adheres to $\mathrm{M}$ cells of rabbit Peyer's patch lymphoid follicle epithelium. The RDEC-1 strain contains an $85 \times 10^{6} \mathrm{D}$ plasmid that codes for pili, which, when purified, adhere to gut absorptive epithelium. This study compared the in vivo lymphoid follicle adherence of the RDEC-1 strain with that of a Shigella flexneri (ShD15) that contained the $85 \times 10^{6} \mathrm{D}$ plasmid and expressed the RDEC-1 pili, a control $E$. coli, and a control $S$. flexneri (ShD12). The bacteria were given in a dose of $10^{10}$ to $0.7-1.1 \mathrm{~kg}$ rabbits. The rabbits were sacrificed at $2,4,6$, and $12 \mathrm{~h}$ postinoculation. Peyer's patch tissue was examined by electronmicroscopy and direct fluorescence microscopy. The piliated ShD15 and RDEC-1 bacteria adhered in large numbers at 2 and $4 \mathrm{~h}$ postinoculation, but only the RDEC1 strain persisted and increased in numbers past that time. Control strains did not adhere. The ShD15 strain adhered to and was rapidly taken into $\mathbf{M}$ cells, precipitating an acute inflammatory reaction within the follicle and adjacent lumen. Initial lymphoid follicle $\mathbf{M}$ cell adherence of the ShD15 strain was associated with the possession of the adherence pilus plasmid. The failure of the ShD15 strain to survive and colonize the lymph follicle epithelium contrasts with the success of the RDEC-1 strain and indicates that the RDEC- 1 strain possesses virulence factors in addition to pili.

\section{Introduction}

Escherichia coli (strain RDEC-1) is a serotype 015:K-:NM bacterium that produces diarrhea in post-weanling rabbits beginning

This paper was published in part in abstract form (1983. Clin. Res. $31: 366 A$ and $880 A$ ). 1984.

Received for publication 1 July 1983 and in revised form 9 March

The Journal of Clinical Investigation, Inc.

Volume 74, July 1984, 90-95
$6 \mathrm{~d}$ postinoculation with as few as 100 bacteria (1). The bacterium adheres to $M$ cells of the Peyer's patch lymphoid follicle epithelium within a few hours postinoculation, causing acute inflammation as early as $12 \mathrm{~h}(2,3)$. The gut lumen is subsequently colonized and by 3-6 d postinoculation, RDEC-1 strain bacteria can be seen adhering closely to the surfaces of ileal, cecal, and colonic absorptive epithelial cells that have been denuded of microvillus border (4). It is at this stage that diarrhea occurs. This close adherence is similar to that described in humans with diarrhea due to enteropathogenic $E$. coli (5-7).

The RDEC-1 strain has been shown to produce pili under certain cultural conditions $(8,9)$. Cheney et al. have shown that the pili are plasmid mediated and that phenotypic expression of the pili is associated with bacterial adherence to partially purified rabbit ileal brush borders (8). The purified RDEC-1 strain pili demonstrate specific adherence to cryostat sections of rabbit intestinal epithelium (10). A nonpathogenic Shigella flexneri $2 \mathrm{a}$ has been transformed by conjugation with the RDEC1 strain $85 \times 10^{6} \mathrm{D}$ plasmid that encodes for pilus synthesis. The presence of the $85 \times 10^{6} \mathrm{D}$ plasmid in the $S$. flexneri strain leads to the synthesis of pili that are immunologically the same as the RDEC-1 pili and that give the shigella strain the ability to adhere in vitro to rabbit ileal brush borders (8). As pili can adhere to gut absorptive epithelium, they might play a role in the adherence of the RDEC-1 strain to Peyer's patch lymphoid follicle $M$ cells. This possibility was examined in vivo in the present study.

\section{Methods}

Bacterial strains. Four bacterial strains, including strain RDEC-1, were tested for their ability to adhere to Peyer's patch lymph follicle epithelium in vivo. E. coli 015:K14:H4 (ATCC 015) ${ }^{1}$ was obtained from the American Type Culture Collection (Rockville, MD; No. 23510) and was

1. Abbreviations used in this paper: ATCC 015, Escherichia coli 015:K14:H4; FITC, fluorescein isothiocyanate; PA, penassay broth; RDEC-1, rabbit enteroadherent enteropathogenic Escherichia coli 015:K:NM; ShD12, Shigella flexneri 2a 2085 D12; ShD15, Shigella flexneri 2a 2085 D15; TSB, tryptic soy broth. 
determined to he nonpathogenic after orogastric administration in rabbits. Two $S$. flexneri 2a strains were obtained from Dr. S. B. Formal (Walter Reed Army Institute of Research, Washington, DC). The strain 2085 D15 (ShD15) contains the $85 \times 10^{6}$ D RDEC-1 strain plasmid, which confers the ability to produce RDEC-1 strain type pili. The strain 2085 D12 (ShD12) was an exconjugate strain that did not acquire the RDEC1 pili plasmid (8). Neither shigella strain produces disease in rabbits, nor do they contain the $140 \times 10^{6} \mathrm{D}$ virulence plasmid characteristic for this species $(8,11)$.

Stock cultures of the four bacterial strains to be tested were stored in tryptic soy broth (TSB) (Difco Laboratories Inc., Detroit, MI) in 50\% glycerol at $-70^{\circ} \mathrm{C}$. Bacteria for rabbit challenge were grown $18 \mathrm{~h}$ at $37^{\circ} \mathrm{C}$ in static penassay broth (PA) (Difco Laboratories Inc.) to elicit pilus expression (8) or in TSB to suppress pilus expression. Bacteria to be grown in PA were serially passed in PA broth to elicit ShD15 and RDEC-1 strain pili-producing phase variants (8). Bacteria from broth cultures were harvested by centrifugation and resuspended in phosphate buffered saline to give a concentration of $10^{10}$ organisms $/ \mathrm{ml}$.

Rabbit challenge. New Zealand white rabbits that weighed 0.7-1.1 $\mathrm{kg}$ were checked for gut colonization by swabbing of the rectum and streaking of the swab onto MacConkey agar plates. Lactose positive colonies were checked by slide agglutination with anti-RDEC-1 serum to be certain that the rabbits were not colonized with the RDEC-1 organism. Rabbits without diarrhea or gut colonization with RDEC-1 were fasted overnight and challenged via orogastric tube with $2 \mathrm{ml}$ of a test strain bacterial suspension $\left(2 \times 10^{10}\right.$ bacteria) followed immediately by $10 \mathrm{ml}$ of $10 \% \mathrm{NaHCO}_{3}$. The dosage of bacteria was increased from the $2 \times 10^{6}$ inoculum of previous work $(2,3)$ to provide more adherent bacteria early postinoculation. The rabbits were then allowed food ad lib. until death.

Preparation of antisera. Antisera to the RDEC-1 and the ShD12 bacteria were prepared in rabbits by intravenous injection of bacteria according to procedures described elsewhere (1). Antibody activity was confirmed by a microagglutination technique that used heat-killed whole bacteria as the antigen (12).

$\operatorname{lgG}$ purification. IgG was precipitated from the antisera by ammonium sulfate and eluted from a diethylaminoethyl cellulose (Whatman DE-52; H. Reeve Angel and Co., Inc. Clifton, $\mathrm{NJ}$ ) column equilibrated with $0.01 \mathrm{M}$ phosphate buffer ( $\mathrm{pH} 7.5$ ). Purified $\mathrm{IgG}$ was checked by double diffusion against goat anti-rabbit IgG to confirm its identity and its antibody activity was titered by the microagglutination technique.
Conjugation of $\operatorname{IgG}$ to fluorescein isothiocyanate. $\operatorname{IgG}$ was labeled with FITC (Research Organics, Inc., Cleveland, $\mathrm{OH}$ ) by the reverse dialysis technique (13). FITC in a proportion of $18 \mu \mathrm{g} / \mathrm{mg}$ of protein was used to label the IgG. The labeled antibody was then used to stain cryostat sections as described below.

Tissue collection for FITC-IgG staining. Rabbits challenged with the different bacterial strains were sacrificed at $2,4,6$, and $12 \mathrm{~h}$ postinoculation by intracardiac injection of a lethal dose of pentobarbital. Immediately after death, the abdomen was opened, the most distal ileal Peyer's patch was located and excised, the lumen was opened, and the tissue was placed mesenteric side down on dental wax. The tissue was frozen at $-70^{\circ} \mathrm{C}$ and cryostat sectioned. and the sections were mounted on glass slides and stained with FITC-IgG specific for the challenged bacterium.

Grading of IgG-FITC stained sections. FITC-IgG stained cryostat sections were examined under an epiluminescent fluorescence microscope (Leitz, Orthoplan; E. Leitz, Inc., Rockleigh, NJ) with the $100 \mathrm{X}$ oil immersion objective. The numbers of fluorescing bacteria per field that adhered to the Peyer's patch follicular epithelium were graded according to the following scale (3): no adherence, 0 ; adherence of single bacteria, 1: one to two aggregates of adherent bacteria, 2; three to five aggregates, 3 ; and six or more aggregates, 4 . The slides were coded so that the microscopist was unaware of their origin. A bacterium was considered adherent to an epithelial cell if it was immediately adjacent to the surface of the cell and if there was no mucus or other material between the bacterium and the cell surface. An aggregate of adherent bacteria was defined as the complete covering of two or more adjacent epithelial cell surfaces with fluorescent bacteria.

Tissue collection for electronmicroscopy: Rabbits challenged with the shigella strains were sacrificed at 2 and $6 \mathrm{~h}$ postinoculation by intracardiac injection of pentobarbital as described above. At that time the abdomen was opened and the most distal ileal Peyer's patch was located and excised. Colonization with $S$. flexneri was determined by the touching of a sterile cotton swab to the lumenal surface of the Peyer's patch, the streaking of the swab onto a MacConkey agar plate, and the identification of colonies by slide agglutination by the use of specific antisera. The tissue was then placed in chilled $2 \%$ glutaraldehyde in $0.1 \mathrm{M}$ cacodylate buffer ( $\mathrm{pH} 7.4$ ) for $15 \mathrm{~min}$, at which time the Peyer's patch was removed, sliced with a razor blade into $1-\mathrm{mm}$ strips, and returned to the fixative overnight at $4^{\circ} \mathrm{C}$. The tissue strips were then washed three times with $0.1 \mathrm{M}$ cacodylate buffer and postfixed with $2 \% \mathrm{OsO}_{4}$ in $0.1 \mathrm{M}$ cacodylate

Table I. Mean Adherence* of Bacteria to Rabbit Peyer's Patch Lymphoid Epithelium

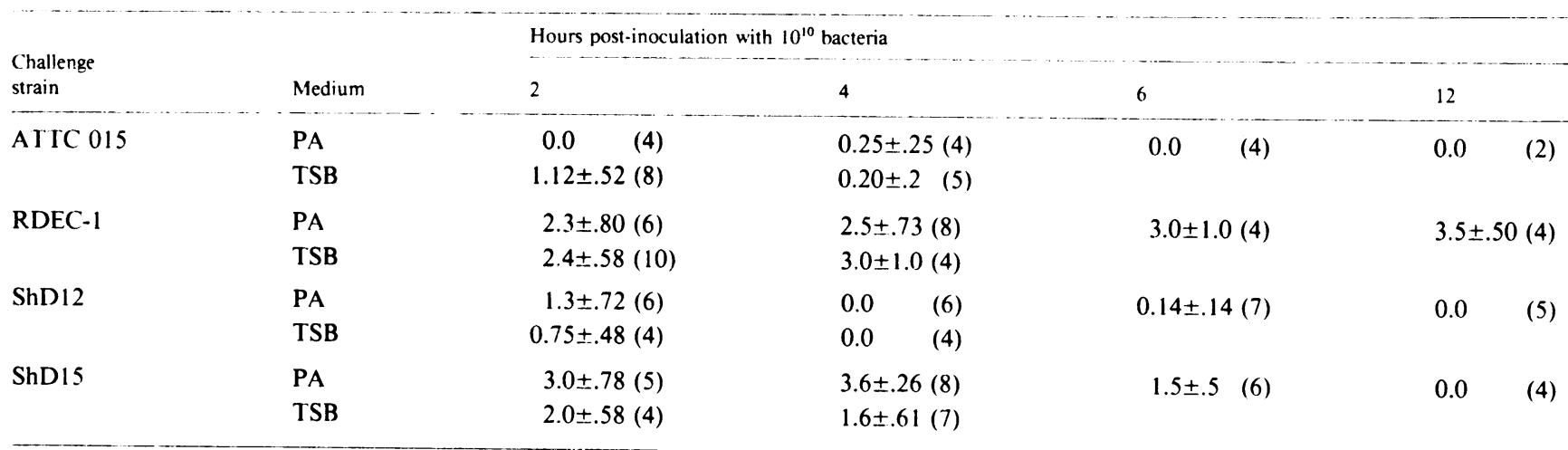

Number in parentheses indicates number of rabbits. * Adherence ( \pm SEM) graded according to the following scale: no adherence, 0 ; adherence of single bacteria, 1; one to two aggregates of adherent bacteria, 2; three to five aggregates, 3; and six or more aggregates, 4 . An aggregate of adherent bacteria was defined as the complete covering of the surfaces of two or more lymphoid follicle epithelial cells with fluorescent bacteria. 


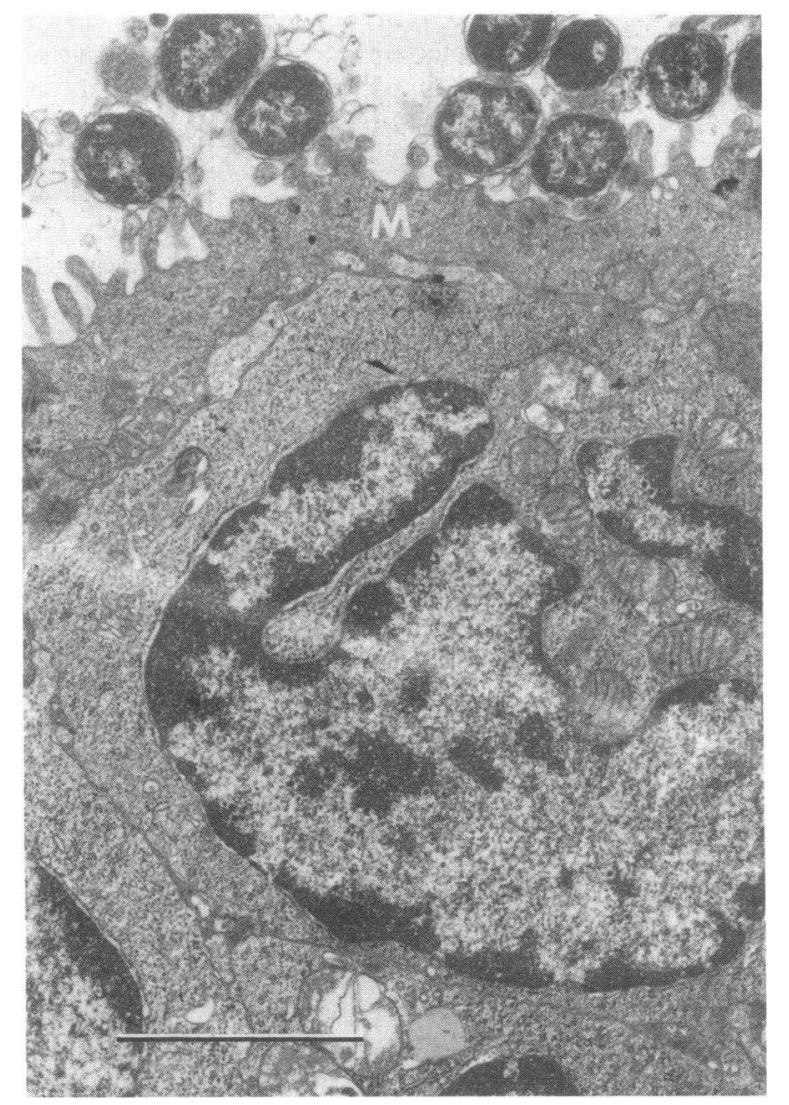

Figure 1. Transmission electron micrograph of Peyer's patch lymphoid follicle epithelium taken $4 \mathrm{~h}$ postinoculation with $10^{10} \mathrm{ShD} 15$ strain bacteria. Organisms are seen within the lumen associated with the lumenal surface projections of $M$ cells (M). Bar, $2 \mu \mathrm{m}$. buffer at room temperature for $3 \mathrm{~h}$. The tissue was then prepared for thick and thin sectioning by embedment in Epon 812 (Electron Microscopy Sciences, Fort Washington, PA) as described previously (2). After postembedment staining with uranyl acetate and lead citrate, sections were examined at an accelerating voltage of $75 \mathrm{kV}$ with a transmission electron microscope (HU12-A; Hitachi, Ltd., Tokyo).

Statistical analysis. The $t$ test (14) was used to determine significant differences between lymph follicle adherence ability for PA-grown inocula of each strain at each hour interval. The significance of differences in lymphoid follicle adherence for TSB- and PA-grown inocula for each strain at 2 and $4 \mathrm{~h}$ postinoculation was also determined by the $t$ test. $P \leq 0.05$ was considered significant.

\section{Results}

Fluorescent antibody. Tissues from 129 rabbits were examined. Table I shows the relative bacterial lymphoid follicle adherence, the number of experimental animals, the bacterial growth media, and the number of hours between challenge and death for each bacterial strain tested.

The adherence aggregate size and density of bacteria in the aggregate were less than in a previous study (3), probably because of the early postinoculation sampling interval or the inability of the ShD15 strain to survive on the epithelium. The physical characteristics of the aggregates made fluorescence photomicrography technically impossible.

The only significant difference in lymph follicle adherence between PA- and TSB-grown inocula occurred in ShD15 strainchallenged animals at the 4 -h interval $(P=0.007)$. Analysis of the Peyer's patch lymphoid follicle adherence of ShD1 5 bacterium by hour postinoculation revealed that at both 4 and 6 $\mathrm{h}$, the ShD1 5 organism adhered to the Peyer's patch to a greater degree than did ShD12 (4 h, $P<0.001 ; 6 \mathrm{~h}, P=0.017$ ). ShD15 strain also adhered to the lymph follicle epithelium to a greater

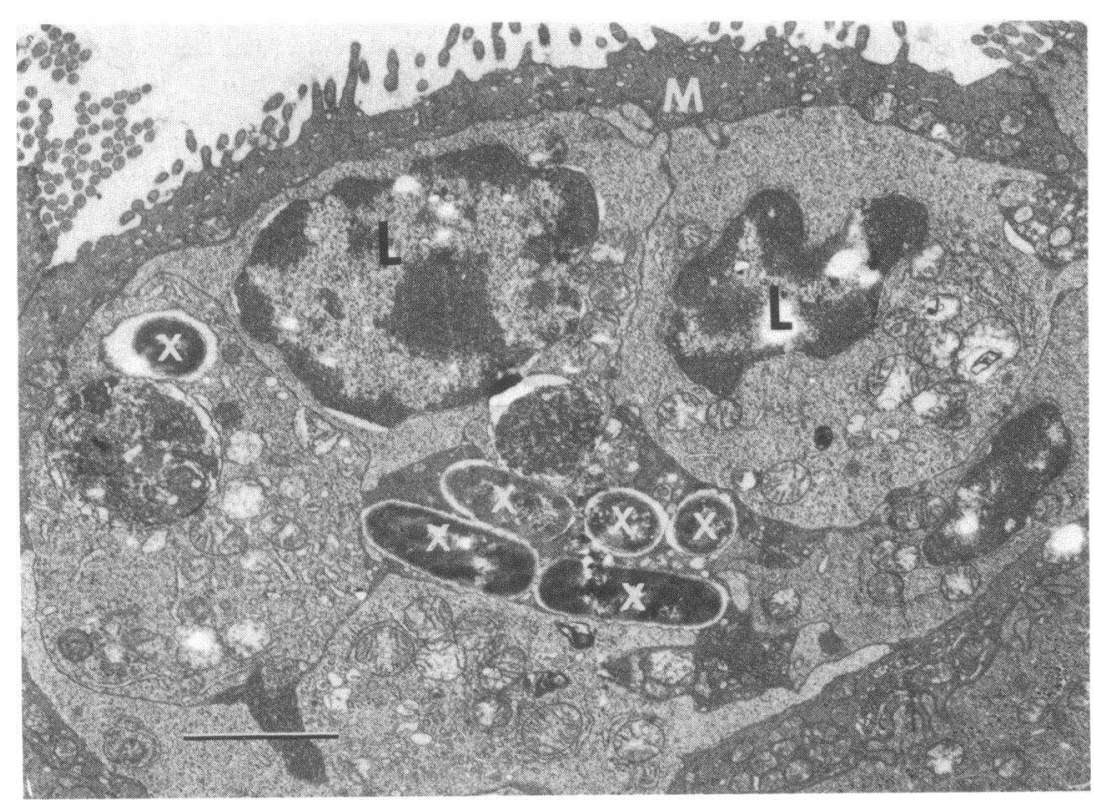

Figure 2. Transmission electron micrograph which shows an $M$ cell $(\mathrm{M})$ and associated lymphocytes (L) of the follicular epithelium from a rabbit Peyer's patch taken $2 \mathrm{~h}$ postinoculation with $10^{10} \mathrm{ShD} 15$ strain bacteria. Bacteria $(X)$ are seen within the epithelium between the lymphocytes. At this time interval there is no evidence of acute inflammatory cells. Bar, $2 \mu \mathrm{m}$. 


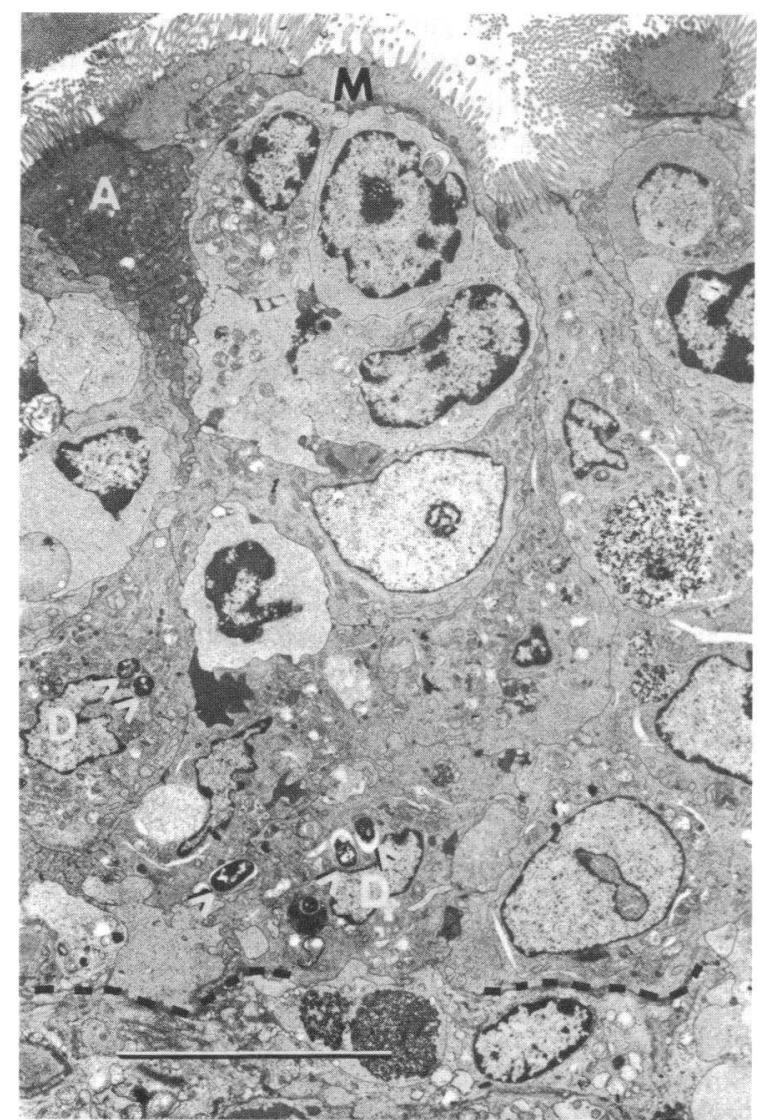

Figure 3. Transmission electron micrograph of a cross section of rabbit Peyer's patch follicular epithelium taken $2 \mathrm{~h}$ postinoculation with $10^{10} \mathrm{ShD} 15$ strain bacteria. The epithelium from basement membrane (-----) to $M$ cell apex (M) is illustrated. Bacteria $(>)$ are seen deep within the epithelium immediately above the basement membrane. Bacteria in this area are associated with dendritic cells (D). Bar, $10 \mu \mathrm{m}$.

extent than did the ATCC 015 strain at 2,4 , and $6 \mathrm{~h}$ postinoculation $(2 \mathrm{~h}, P=0.011 ; 4 \mathrm{~h}, P<0.001 ; 6 \mathrm{~h}, P=0.042)$. ShD15 and RDEC-1 strain adherence were not significantly different until $12 \mathrm{~h}$ postinoculation, at which time ShD15 adherence was not evident while RDEC-1 adherence was at a maximum $(P<0.001)$.

Electronmicroscopy. Tissues from 15 rabbits were available for use in this study. Tissue was examined from nine amimals challenged with PA-grown ShD15 strain bacteria. Four of these animals were killed at $2 \mathrm{~h}$, three at $4 \mathrm{~h}$, and two at $6 \mathrm{~h}$ postinoculation. Tissue from six animals challenged with PA-grown ShD1 2 strain bacteria were examined; four were killed at $2 \mathrm{~h}$ and two at $6 \mathrm{~h}$ postinoculation.

Lymphoid follicle epithelium from Peyer's patch tissues of rabbits challenged with ShD12 strain bacteria af both 2 and 6 $\mathrm{h}$ postinoculation had no associated bacteria (2). Furthermore, the lymph follicle epithelium was intact and there was no infiltration of inflammatory cells.
In contrast, Peyer's patch lymph follicle tissue taken from all ShD1 5 strain-challenged rabbits at 2 and $4 \mathrm{~h}$ postinoculation showed bacteria in the lumen over the follicular epithelium (Fig. 1). In addition, six of the seven of these rabbits showed bacteria within the epithelium of the lymph follicle closely associated with intraepithelial lymphocytes within the $M$ cells (Fig. 2). Bacteria present near the basement membrane were seen associated with cell bodies or cytoplasmic processes (Fig. 3) characteristic of nonlymphocytic dendritic cells (15). At $6 \mathrm{~h}$ postinoculation, all tissues from ShD15 strain-challenged rabbits displayed bacteria and polymorphonuclear leukocytes in the lumen, bacteria and polymorphonuclear leukocytes within the lymph follicle epithelium, and areas of erosion of the lymph follicle epithelium (Fig. 4). Bacteria were not seen over or within the absorptive epithelium of adjacent villi.

\section{Discussion}

The results of the present study support the hypothesis that pili play a role in the specific initial adherence of the RDEC-1 strain

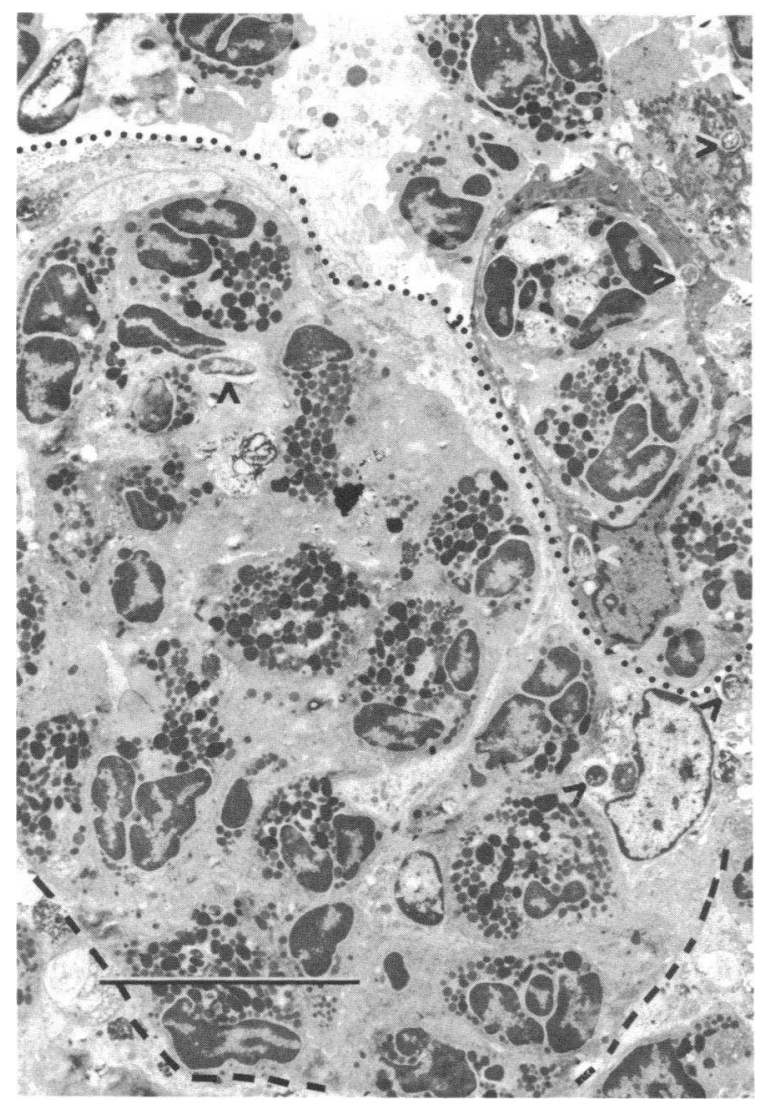

Figure 4. Transmission electron micrograph of a rabbit Peyer's patch lymphoid follicle epithelium taken $6 \mathrm{~h}$ postinoculation with $10^{10}$ ShD15 strain bacteria. The infiltration of large numbers of inflammatory cells into the epithelium obscured the normal architecture and resulted in erosion of the epithelium and spilling of leukocytes into the lumen. . . . . lumenal surface; --.--, basement membrane; $>$, bacteria. Bar, $10 \mu \mathrm{m}$. 
to $\mathbf{M}$ cells of Peyer's patch epithelium. These same pili, which can be transferred via a plasmid to other bacteria, also mediate specific bacterial adherence to partially purified rabbit ileal brush borders (8) and, in purified form, adhere to rabbit intestinal epithelium (10). The specific adherence to the Peyer's patch epithelium was manifested as an adherence significantly greater than that of controls at $2 \mathrm{~h}$ postinoculation and as an ability to maintain or increase a presence on the follicles beyond that interval.

The specifically adhering strains were grown in culture media that suppressed (TSB) or encouraged (PA) the synthesis of pili by $>90 \%$ of bacteria $(8,9)$. It was hoped that cultural-induced differences in pilus expression might further confirm the pivotal role of pili in lymphoid follicle adherence. However, culture media had no effect on the adherence of the RDEC-1 strain, and the ShD15 strain grown in PA adhered better only at $4 \mathrm{~h}$ postinoculation. There are several possible explanations for these data. The small percentage of $10^{10}$ bacteria grown in TSB that could be piliated might be sufficient to account for a portion of the adherence. Also, 2 to $4 \mathrm{~h}$ might be enough time for bacteria to synthesize and express pili, so that the percentage of piliated bacteria could increase in vivo. The RDEC-1 strain, which, in contrast to the ShD15 strain, is known to successfully colonize the rabbit gut, should have the advantage in synthesizing pili in vivo. Finally, nonpilus adherence factors, the expression of which might not be affected by culture media, may be transferred with the pilus plasmid. A nonpilus colonization factor has been described among $\mathrm{K} 88$ strains of enterotoxigenic $E$. coli that colonize and cause diarrhea in neonatal pigs (16). The ability of certain uropathogenic $E$. coli to cause mannose resistant hemagglutination, once thought to be due to pili, has been transferred to other bacteria independent of the pili (17), indicating a role for nonpilus structures in some types of bacterial adherence.

The RDEC-1 strain and the ShD15 strain exhibit striking differences in their ability to survive and prosper at the lymphoid follicle surface. The RDEC-1 strain increases in number and remains on the lymphoid follicle epithelium for up to $14 \mathrm{~d}$ postinoculation (3). The ShD15 strain was found in greatest numbers 2 and 4 h postinoculation but was lost shortly thereafter. The RDEC-1 strain causes the loss of microvilli and adheres closely to lymphoid follicle epithelium (2). It is rarely taken into the follicle epithelium and its presence in large numbers on the lymphoid follicle epithelium does not precipitate an acute inflammatory response in the follicle dome until 12-24 $\mathrm{h}$ postinoculation. The ShD15 strain, in contrast, is seen primarily in the lumen adjacent to $M$ cells and near the basement membrane of the follicular epithelium. Although small numbers of bacteria were seen that closely approximated M cell microvilli, the ShD15 strain did not destroy microvilli nor did it remain on the epithelium in large numbers. The inflammatory response its presence precipitated was dramatic and resulted in disruption of the epithelium by migrating leukocytes. The failure of the ShD15 strain to persist on the lymphoid follicle epithelium could be due to something as simple as a lack of the metabolic machinery to use nutrients in the rabbit gut. However, it seems as likely that the RDEC-1 strain has additional virulence factors that allow it to adhere closely in large numbers to the lymphoid epithelium without being taken into the epithelium or precipitating so acute an inflammatory response.

The ability of a pilus protein, such as that synthesized by the RDEC-1 strain, to confer the ability to adhere to Peyer's patch lymphoid epithelium, enter the tissue, and stimulate a tissue response to non-RDEC-1 strain bacteria, is potentially very important for vaccines designed to protect mucosal surfaces $(18,19)$. Given the similarity in histopathology, the most likely candidates for similar strains in humans would be enteroadherent strains of enteropathogenic $E$. coli (5-7).

\section{Acknowledgments}

We express our appreciation to Dr. S. B. Formal, Department of Bacterial Diseases, Walter Reed Army Institute of Research, Washington, DC for providing the two Shigella exconjugates used in this study. We also thank R. K. Blake and Linda W. Mann for their excellent technical assistance and Brenda $\mathrm{H}$. Warren for her patience in the preparation of this manuscript.

This work was supported by the Veterans Administration and The World Health Organization.

\section{References}

1. Cantey, J. R., and R. K. Blake. 1977. Diarrhea due to Escherichia coli in the rabbit: a novel mechanism. J. Infect. Dis. 135:454-462.

2. Inman, L. R., and J. R. Cantey. 1983. Specific adherence of Escherichia coli (strain RDEC-1) to membranous (M) cells of the Peyer's patch in Escherichia coli diarrhea in the rabbit. J. Clin. Invest. 71:1-8.

3. Cantey, J. R., and L. R. Inman. 1981. Diarrhea due to Escherichia coli strain RDEC-1 in the rabbit: the Peyer's patch as the initial site of attachment and colonization. J. Infect. Dis. 143:440-446.

4. Takeuchi, A., L. R. Inman, P. D. O'Hanley, J. R. Cantey, and W. B. Lushbaugh. 1978. Scanning and transmission electron microscopic study of Escherichia coli 015 (RDEC-1) enteric infection in rabbits. Infect. Immun. 19:686-694.

5. Ulshen, M. H., and J. L. Rollo. 1980. Pathogenesis of Escherichia coli gastroenteritis in man-another mechanism. N. Engl. J. Med. 302:99-101.

6. Rothbaum, R., A. J. McAdams, R. Giannella, and J. C. Partin. 1982. A clinicopathologic study of enterocyte-adherent Escherichia coli: a cause of protracted diarrhea in infants. Gastroenterology. 83:441-454.

7. Clausen, C. R., and D. L. Christie. 1982. Chronic diarrhea in infants caused by adherent enteropathogenic Escherichia coli. J. Pediatr. 100:358-361.

8. Cheney, C. P., S. B. Formal, P. A. Schad, and E. C. Boedeker. 1983. Genetic transfer of a mucosal adherence factor (R1) from an enteropathogenic Escherichia coli strain into a Shigella flexneri strain and the phenotypic suppression of this adherence factor. J. Infect. Dis. 147:711-723.

9. Cantey, J. R., W. B. Lushbaugh, and L. R. Inman. 1981. Attachment of bacteria to intestinal epithelial cells in diarrhea caused by Escherichia coli strain RDEC-1 in the rabbit: stages and role of capsule. J. Infect. Dis. 143:219-230.

10. Berendsen, R., C. P. Cheney, P. A. Schad, and E. C. Boedeker. 1983. Species-specific binding of purified pili (AF/R1) from the Escherichia coli RDEC-1 to rabbit intestinal mucosa. Gastroenterology 85:837-845. 
11. Silva, R. M., M. R. F. Toledo, and L. R. Trabulski. 1982. Plasmidmediated virulence in Shigella species. J. Infect. Dis. 146:99. (Abstr.)

12. Edwards, P. R., and W. H. Ewing. 1972. Identification of Enterobacteriaceae. Burgess Publishing Co., Minneapolis. 67-101.

13. Morgante, O., E. P. Ambrosie, M. Haraphongse, R. P. Lam, and R. S. Fraser. 1978. Conjugation of cocksackievirus types B1-B6 immunoglobulins with fluorescein isothiocyanate by a reversed dialysis method. J. Infect. Dis. 137:802-809.

14. Schor, S. S. 1968. Fundamentals of Biostatistics. G. P. Putnam's Sons, New York. 145-173.

15. Wilders, M. M., T. Sminia, B. E. C. Plesch, H. A. Drexhage, E. F. Welte-Vreden, and S. G. M. Meuwissen. 1983. Large mononuclear Ia-positive veiled cells in Peyer's patches. II. Localization in rat Peyer's patches. Immunology. 48:461-467.
16. Hohman, A., and M. R. Wilson. 1975. Adherence of enteropathogenic Escherichia coli to intestinal epithelium in vivo. Infect. Immun. 12:866-880.

17. Normark, S., D. Lark, R. Hull, M. Norgren, M. Baga, P. O'Hanley, G. Schoolnik, and S. Falkow. 1983. Genetics of digalactoside-binding adhesin from a uropathogenic Escherichia coli strain. Infect Immun. 41:942-949.

18. Sminia, T., E. M. Janse, and M. M. Wilders. 1982. Antigentrapping cells in Peyer's patches of the rat. Scand. J. Immunol. 16:481485 .

19. Owen, R. L. 1983. And now pathophysiology of M cellsgood news and bad news from Peyer's patches. Gastroenterology. 85:468-470. 